Industrial Health, 1979, 17, 187.

\title{
SOLUBILITY AND CELL TOXICITY OF CADMIUM
}

\author{
Kimiko KOSHI \\ National Institute of Industrial Health, Nagao 6-chome, Tama-ku, \\ Kawasaki 213, Japan
}

(Received November 9, 1979)

\begin{abstract}
Cadmium (Cd), Cd fume and cadmium oxide (CdO) were more easily dissolved in protein and amino acid solution such as fetal calf serum, albumin, glycine or neutralized cysteine monohydrate solution than in water or Tyrode's solution. But, there was no difference in the dissolution of cadmium sulphite (CdS) between in the former solutions and in the latter. The solubility of $\mathrm{Cd}$, $\mathrm{CdO}$ or $\mathrm{Cd}$ fume in albumin and glycine solution increased with increasing their concentration.

When the Cd dissolved in protein or amino acid solution was added to the cultures, these dissolved $\mathrm{Cd}$ showed toxic action on the FM3A cells in proportion to the amount of $\mathrm{Cd}$ value irrespective of the sort of the solvent.

On the column chromatographs by gel filtration on Sephadex G-200, the Cd dissolved in albumin solution or fetal calf serum coexisted with albumin fractions. In the case of the culture medium containing the $\mathrm{Cd}$ dissolved in albumin solution or fetal calf serum, the Cd was also associated with albumin fractions. When, however, metallothionein-Cd was added to the cultures, the $\mathrm{Cd}$ in the culture medium was combined mainly with metallothionein fractions and partly with albumin fractions and the Cd bound with thionein did not show the toxic action on the FM3A cells.
\end{abstract}

In the previous papers ${ }^{12)}$, it was observed that the solubility of $\mathrm{Cd}$ fume and $\mathrm{CdO}$ in Tyrode's solution or distilled water was remarkably enhanced by the addition of serum, albumin or amino acids such as glycine, alanine or cystein monohydrate and the dissolved $\mathrm{Cd}$ in protein and amino acid solutions showed toxic actionon an the macrophages and 3T6 fibroblasts in culture.

In this paper, the increased solubility of metallic $\mathrm{Cd}$ and some particulate $\mathrm{Cd}$ compounds in protein or amino acid solution was confirmed and then it was studied whether the $\mathrm{Cd}$ dissolved in protein or amino acid solution was combined with protein or not in the cultures. Futhermore, it was studied whether or not Cd-protein complex was less toxic than the equivalent amount of ionic $\mathrm{Cd}^{2}$, if $\mathrm{Cd}$ was combined with protein in the cultures.

\section{MATERIALS AND METHODS}

Chemicals and biological materials

$\mathrm{Cd}$ fume: The $\mathrm{Cd}$ fume was generated from $\mathrm{Cd}$ metal with the high frequency 


\section{K. KOSHI}

induction furnace which was described in the previous papers ${ }^{344)}$. The purity grade of the sample metal of $\mathrm{Cd}$ was $99.999 \%$. The particle size (geometric) of $\mathrm{Cd}$ fume used in this experiment was $0.72-1.12$ micron.

Cd powder: Metallic Cd powder was purchased from Wako Pure Chemical Industries Ltd. and the $\mathrm{Cd}$ powder was sieved below 325 mesh before use.

$\mathrm{CdO}, \mathrm{Cd}$ chloride $\left(\mathrm{CdCl}_{2} \cdot 2^{1} /{ }_{2} \mathrm{H}_{2} \mathrm{O}\right)$ and $\mathrm{Cd}$ sulphide (CdS): The former two samples were purchased from Wako Pure Chemical Industries Ltd. (special grade) and the latter from Koso Chemical Co Ltd.

Metallothionein Cd: This was kindly presented by Dr. M. Kimura in our Institute. This metallothionein-Cd was prepared from rabbit liver and the preparing method was described in his paper ${ }^{5)}$.

Albumin: The crystalline bovine albumin was purchased from Sigma Chemical Company.

Fetal calf serum: Sterile fetal calf serum was purchased from Gibco Company.

Glycine and cysteine monohydrate: These were purchased from Wako Pure Chemical Company. (special grade)

\section{The solubility experiment}

Triple distilled water, Tyrode's solution, fetal calf serum and $2 \%$ albumin, $2 \%$ glycine or $2 \%$ neutralized cysteine monohydrate water or Tyrode's solution was used as the solvents.

Two milligrams of each $\mathrm{Cd}$ sample were suspended in $10 \mathrm{ml}$ of each solution and then these suspensions were dispersed for 2 minutes by ultrasonic vibration $(29 \mathrm{KHz}$. $45 \mathrm{~W}$ ). These dispersed suspensions were centrifuged at 60,000 r.p.m. for $30 \mathrm{~min}$ to separate the supernatant. The $\mathrm{Cd}$ content of each supernatant was determined by an atomic absorption spectrometer with an acetylene flame (Hitachi Type 308).

Cell toxicity and the determination of the amount of $\mathrm{Cd}$ in the culture medium.

Effects of the $\mathrm{Cd}$ samples dissolved in various solvents on the cultured FM3A, (a $\mathrm{C} 3 \mathrm{H}$ mouse mammary carcinoma cell line) were examined. The cells were cultured in minimal essential medium (MEM) supplemented with $10 \%$ fetal calf serum. Each sample of $\mathrm{Cd}$ dissolved in various solvents was added to the cultures after sterilization by filtration through Millipore membrane filter ( 0.22 micron pore size). The cell suspensions $\left(1 \times 10^{5}\right.$ cells $/ \mathrm{ml}$ ) containing various concentrations of each dissolved $\mathrm{Cd}$ sample were incubated at $37^{\circ} \mathrm{C}$ in an atomosphere of $5 \% \mathrm{CO}_{2}$ in air. In the control, the same amounts of the each solvent solution were added to the cultures. After incubation for 48 hours, the number of cells was counted in a hemocytometer.

After the determination of the cell toxicity the cultures were centrifuged at 1,500 r.p.m. for $5 \mathrm{~min}$ to remove cells. The amount of $\mathrm{Cd}$ in each supernatant was determined with an atomic absorption spectrometer. 


\section{SOLUBILITY AND CELL TOXICITY OF CADMIUM}

\section{Column chromatography}

This was done on columns of Sephadex G-200 obtained from Pharmacia Fine Chemicals which were packed in $2.5 \times 50 \mathrm{~cm}$ column. Elution was performed with $0.1 \mathrm{M}$ Tris- $\mathrm{HCl}$ buffer ( $\mathrm{pH} 8.0$ ) containing $0.02 \%$ sodium azaide. The flow rate was kept at $20 \mathrm{ml} / \mathrm{hr}$. The fractions were collected with a fraction collector (LKB Co.) and each fraction volume was kept at $5.1 \mathrm{ml}$. The protein concentration in the collected fractions was determined as absorbancy at $280 \mathrm{~m} \mu$ or $250 \mathrm{~m} \mu$ with a spectrophotometer and the $\mathrm{Cd}$ content in these fractions was determined with an atomic absorption spectrometer. The $\mathrm{Cd}$ dissoved from $\mathrm{CdO}$ in fetal calf serum and $2 \%$ albumin Tyrode's solution were used as samples. The supernatants of the culture medium were also used as samples. After determination of cell toxicity, the cultures were centrifuged at 1,500 r.p.m. for $5 \mathrm{~min}$ to remove the cell and the supernatant was submitted to gel filtration.

In this column, $\gamma$-globulin (molecular weight (M.W.) 160,000), albumin (M.W. 60,000), and myoglobulin (M.W. 16.000) could be separated as protein of known molecular weight and it was confirmed that the correlation between the elution volume and molecular weight was linear.

\section{RESULTS}

\section{Dissolution of $C d$ samples}

The results obtained in the solubility experiment of $\mathrm{Cd}, \mathrm{Cd}$ fume, $\mathrm{CdO}$ and $\mathrm{CdS}$ are shown in Table 1. The supernatants from the suspensions of the various samples in water contained very small amounts of $\mathrm{Cd}$. When the fetal calf serum was used as solvent, the amounts of $\mathrm{Cd}$ in the supernatants from $\mathrm{Cd}, \mathrm{Cd}$ fume and $\mathrm{CdO}$ suspensions were about 5 to 20 times as much as those in supernatants in water. When the albumin, glycine or neutralized cysteine monohydrate solution was used as solvent, the amounts of $\mathrm{Cd}$ in the supernatants from $\mathrm{Cd}, \mathrm{Cd}$ fume and $\mathrm{CdO}$ suspensions was higher than in the serum. While in the case of CdS, there was no significant difference in the amount of dissolved $\mathrm{Cd}$ between in water and in protein or amino acid solution. The dissolutions of Cd samples in Tyrode's solution were about equal to those in the water. When Tyrode's solution containing protein or amino acid was used as solvents, the dissolutions of above $\mathrm{Cd}$ samples were about equal to those in water containing amino acid or protein.

Table 1. The amounts of Cd dissolved in various solvents

\begin{tabular}{|c|c|c|c|c|c|c|}
\hline Solvent & $\begin{array}{c}\text { Water } \\
(\mu \mathrm{g} / \mathrm{m} l)\end{array}$ & $\begin{array}{l}\text { Fetal calf } \\
\text { serum } \\
(\mu \mathrm{g} / \mathrm{m} l)\end{array}$ & $\begin{array}{c}2 \% \text { albumin } \\
(\mu \mathrm{g} / \mathrm{m} l)\end{array}$ & $\begin{array}{c}2 \% \text { glycine } \\
(\mu \mathrm{g} / \mathrm{m} l)\end{array}$ & $\begin{array}{c}2 \% \text { neutralized } \\
\text { cysteine monohydrate } \\
(\mu \mathrm{g} / \mathrm{m} l)\end{array}$ & $\begin{array}{c}0.01 \% \\
\text { NaEDTA } \\
(\mu \mathrm{g} / \mathrm{m} l)\end{array}$ \\
\hline $\mathrm{Cd}$ & 2.3 & 11.9 & 29.3 & 84.9 & 91.8 & 99.2 \\
\hline $\mathrm{Cd}$ fume & 3.2 & 34.9 & 62.0 & 112.5 & 119.7 & 107.2 \\
\hline $\mathrm{CdO}$ & 1.0 & 21.5 & 66.5 & 147.8 & 151.2 & 117.2 \\
\hline CdS & 1.1 & 1.2 & 2.5 & 1.2 & 1.9 & 7.2 \\
\hline
\end{tabular}




\section{K. KOSHI}

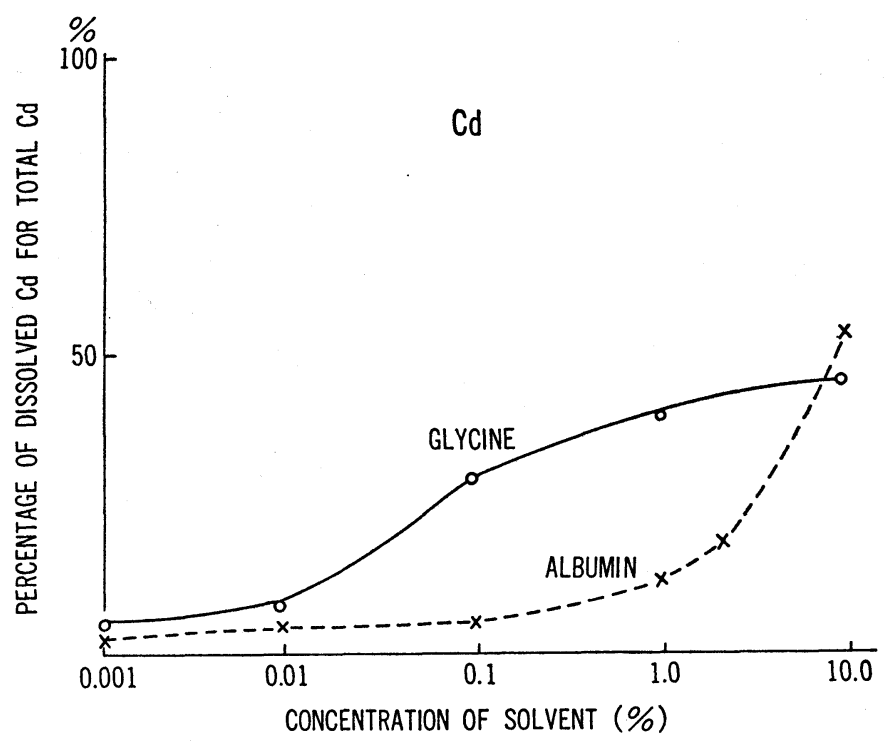

Fig. 1. Solubility and solvent concentration

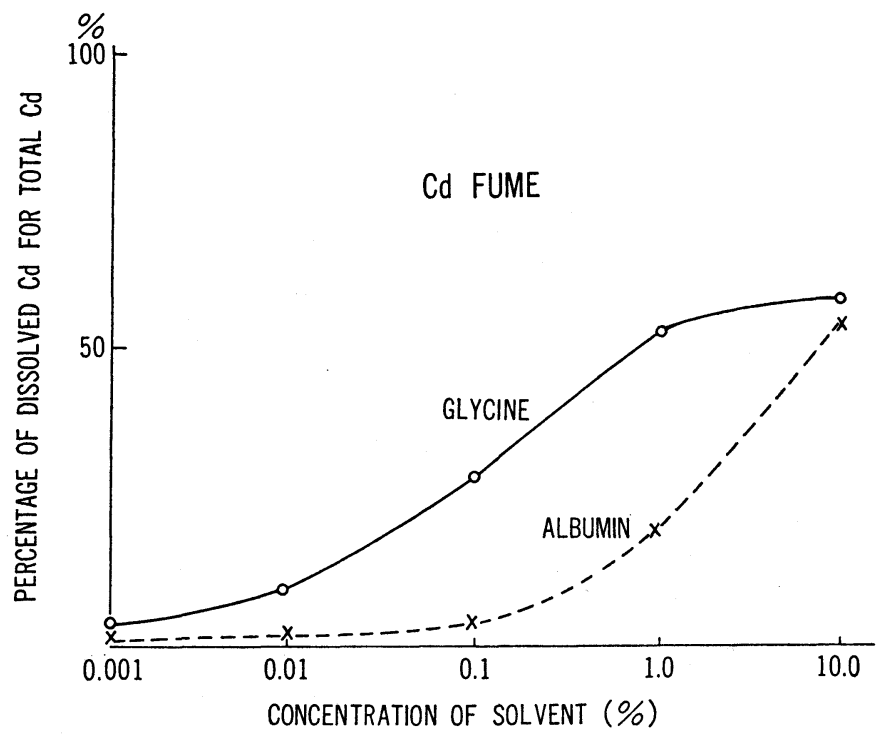

Fig. 2. Solubility and solvent concentration

\section{Relation between the solubility and solvent concentration}

Water solution of various concentrations of albumin and glycine were used as solvent. The albumin or glycine concentrations were $0.001,0.01,0.1,1$ and $10 \%$. The experimental results are shown in Figs. 1 to 4. As seen in the Figs. 1 to 3, the dissolution curves of $\mathrm{Cd}$ against concentration of glycine and albumin showed different patterns. In the glycine solution, the dissolution of $\mathrm{Cd}$ from $\mathrm{Cd}$ powder, $\mathrm{Cd}$ fume and $\mathrm{CdO}$ rapidly increased from $0.01 \%$ and was almost saturated over $1 \%$. In albumin solution, however, the dissolutions 


\section{SOLUBILITY AND CELL TOXICITY OF CADMIUM}

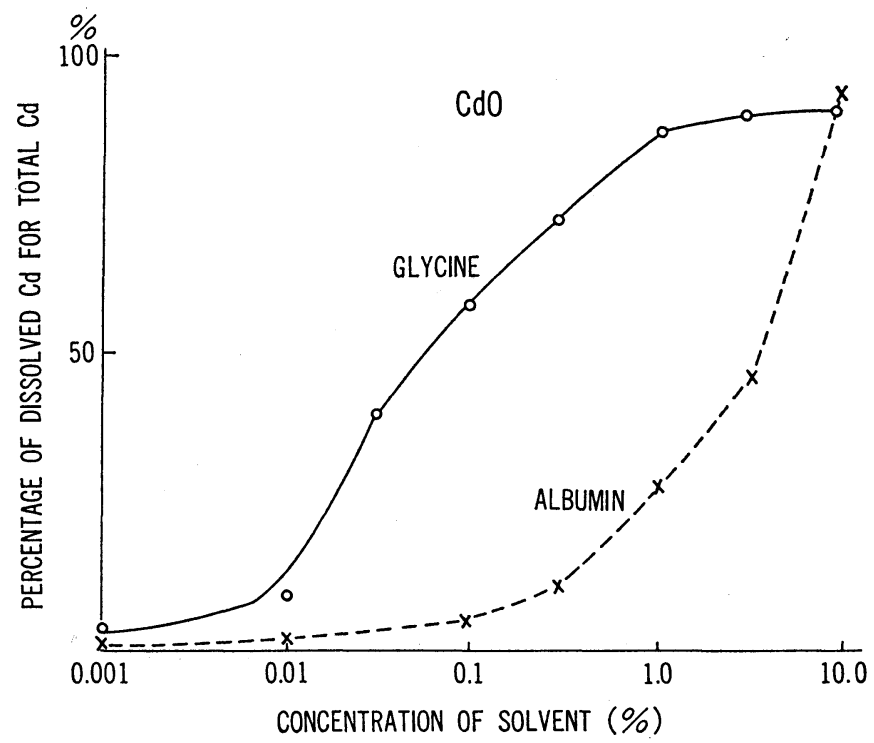

Fig. 3. Solubility and solvent concentration

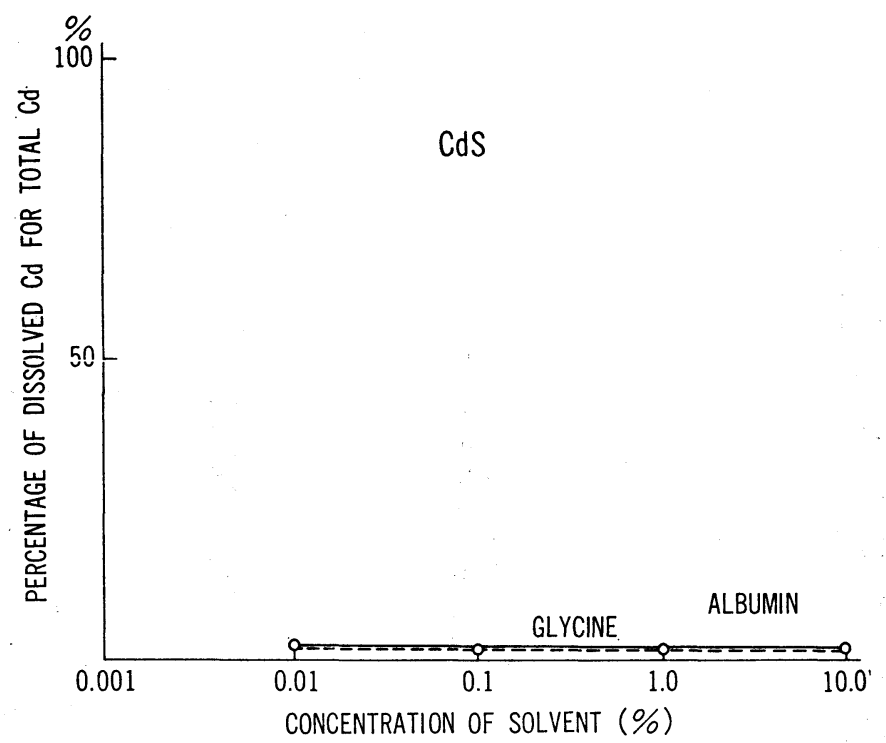

Fig. 4. Solubility and solvent concentration

were very rapid over $1 \%$, while it was slow under $1 \%$ and the dissolution increased with increasing albumin concentration until 10\%. The dissolution of CdS in albumin or glycine solution did not increase in albumin or glycine concentration from $0.01 \%$ to $10 \%$ as shown in Fig. 4.

\section{Cell toxicity of the dissolved $\mathrm{Cd}$}

The results are shown in Fig. 5. As shown in the Figure, the $\mathrm{Cd}$ dissolved from 


\section{K. KOSHI}

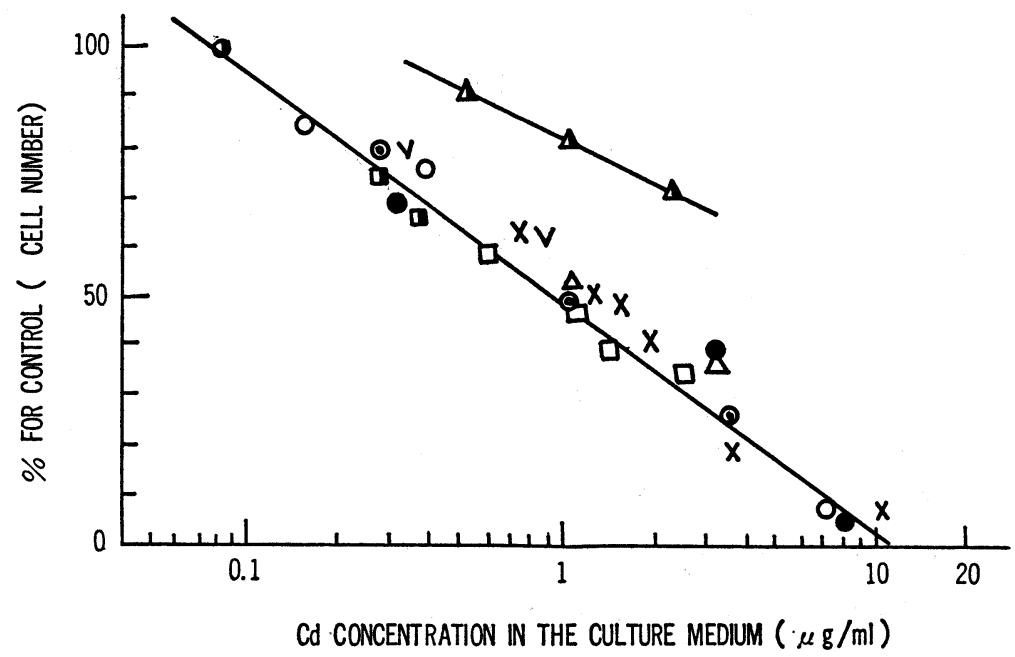

Fig. 5. The cell toxicity of dissolved $\mathrm{Cd}$ and metallothionein-Cd.
$\times$ CdO-10\% FCS MEM
$\triangle$ CdO-cysteine-TS
$\bigcirc$ Cd fume-cysteine-TS
$\square$ CdO-glycine-TS
- CdO-albumin-TS
a CdO-FCS
- CdS-cysteine-TS
(?) $\mathrm{CdCl}_{2}$ in $10 \%$ FCS MEM
$\checkmark$ CdO-NaEDTA
$\triangle$ metallothionein-Cd

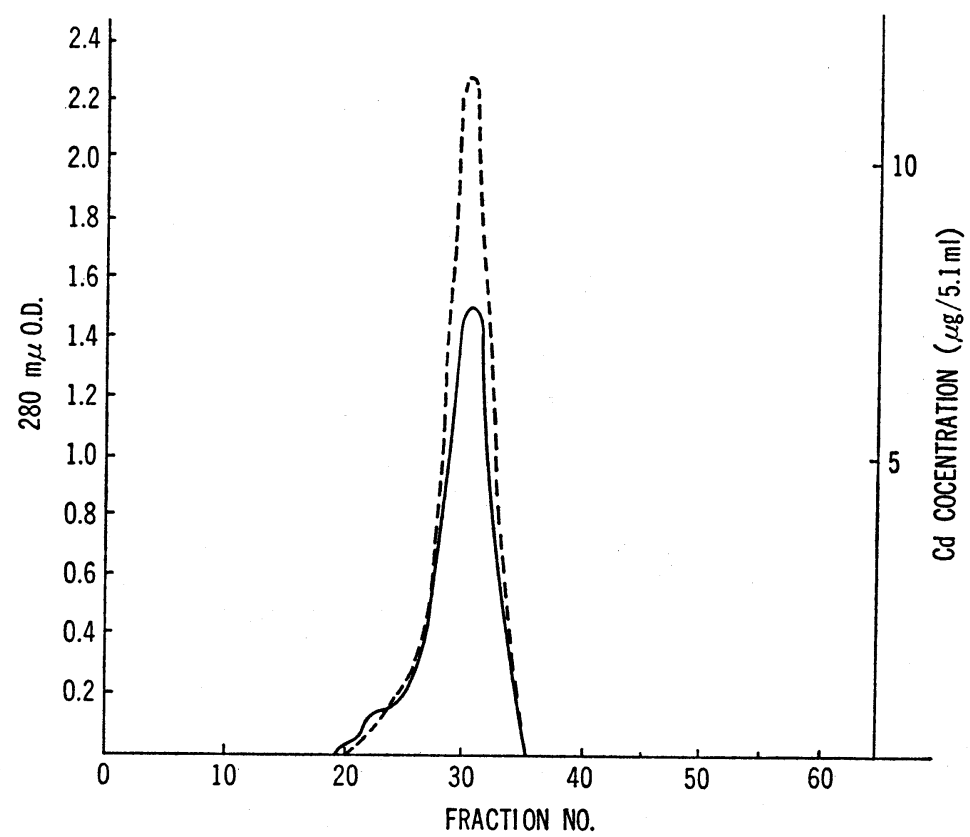

Fig. 6. Fractionation of Cd-albumin solution by gel filtration on Sephadex G-200. Cd concentration $280 \mathrm{~m}$ Optical desity

(The sample applied to the column contained $55 \mu \mathrm{g} \mathrm{Cd}$.) 


\section{SOLUBILITY AND CELL TOXICITY OF CADMIUM}

$\mathrm{CdO}$ in albumin-, glycine-and cysteine-Tyrode's solution and fetal calf serum showed cell toxicity in proportion to $\mathrm{Cd}$ values irrespective of the sort of the solvent. When the $\mathrm{Cd}$ dissolved from $\mathrm{CdO}$ in MEM supplemented with $10 \%$ fetal calf serum was added to the cultures, the cell toxicity of this dissolved $\mathrm{Cd}$ also was as strong as those in the above cases. When $\mathrm{CdCl}_{2}$ dissolved in MEM supplemented with $10 \%$ fetal calf serum $(100 \mu \mathrm{g} / \mathrm{ml})$ was added to the cultures, the toxic action of this dissolved Cd was as strong as the $\mathrm{Cd}$ dissolved in various solvents. In the cases of dissolved $\mathrm{Cd}$ from $\mathrm{Cd}$ fume and CdS in cysteine-Tyrode's solution, the correlations between the $\mathrm{Cd}$ value and cell toxicity were the same as those in the above cases.

\section{Column chromatographs of dissolved $C d$}

The $\mathrm{Cd}$ dissolved from $\mathrm{CdO}$ in $2 \%$ albumin-Tyrode's solution or fetal calf serum was separated by gel filtration. In the case of dissolved $\mathrm{Cd}$ in $2 \%$ albumin solution, the Cd was completely associated with albumin fractions as shown in Fig. 6 . In the case of the dissolved $\mathrm{Cd}$ in fetal calf serum, the $\mathrm{Cd}$ was almost associated with albumin fractions as shown in Fig. 7.

After the determination of the cell toxicity, the supernatants of the cultures were separated by gel filtration. In the case of the supernatants of the culture containing $\mathrm{Cd}$ dissolved in $2 \%$ albumin-Tyrode's solution or in fetal calf serum, the dissolved $\mathrm{Cd}$ in

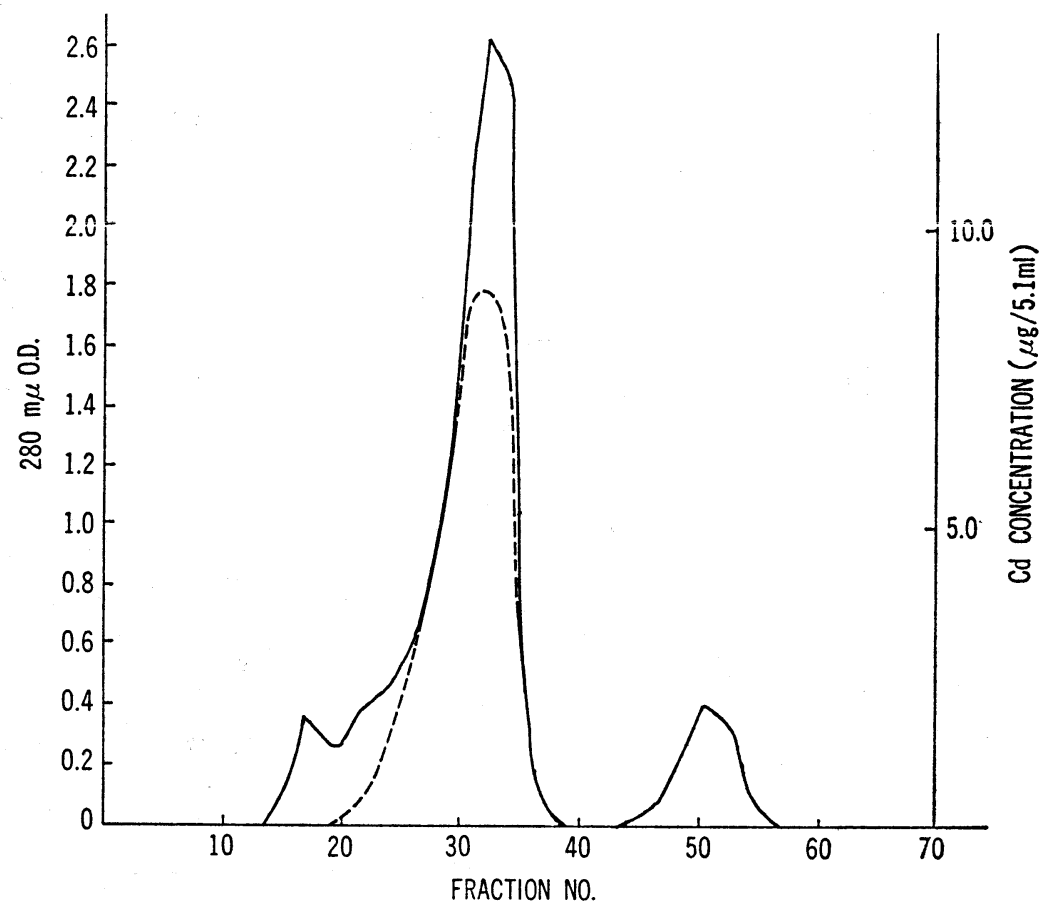

Fig. 7. Fractionation of Cd-serum by gel filtration on Sephadex G-200.

--- Cd concentration $-280 \mathrm{~m}$ Optical density

(The sample applied to the column contained $90 \mu \mathrm{g} \mathrm{Cd}$ ) 
K. KOSHI

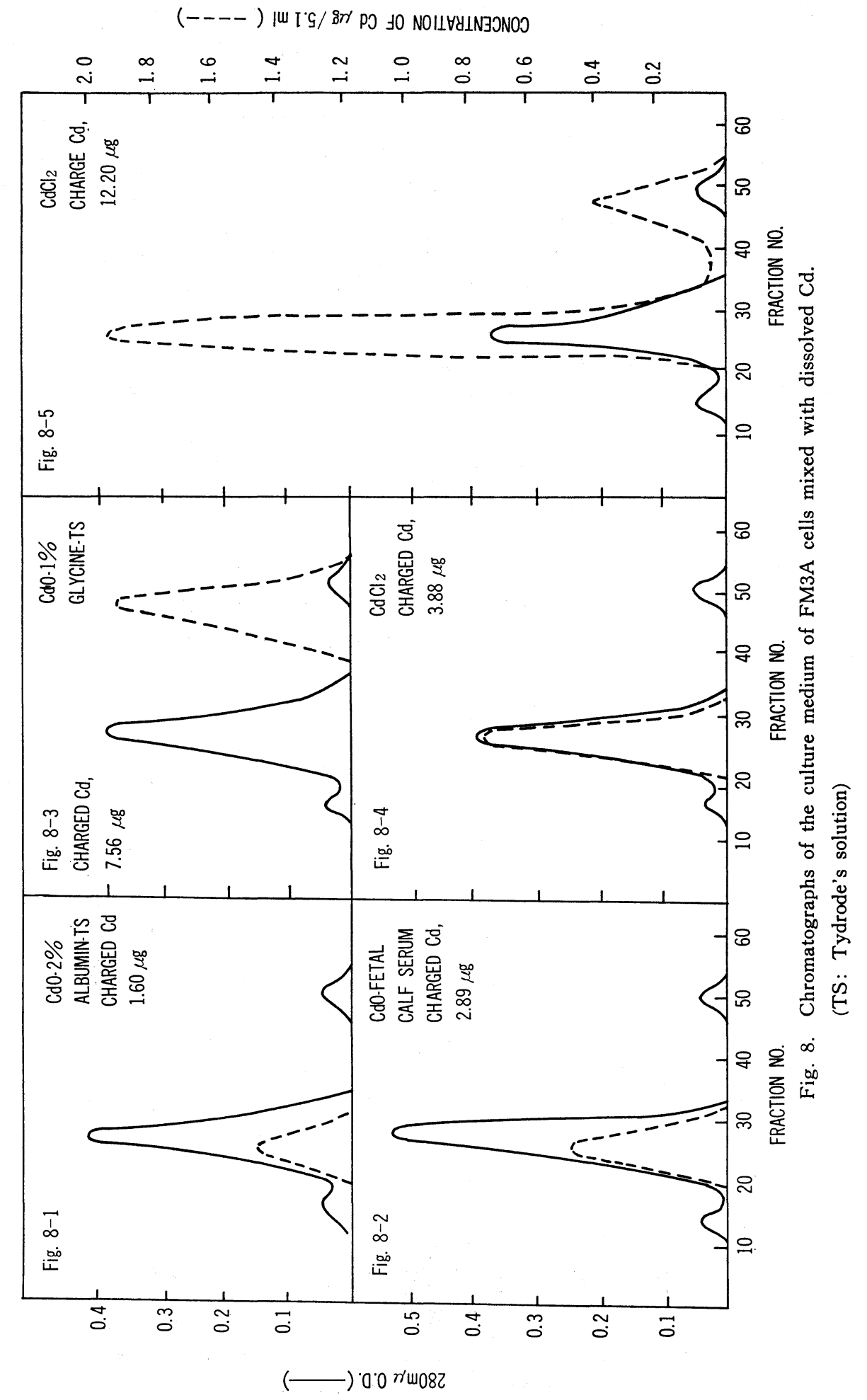




\section{SOLUBILITY AND CELL TOXICITY OF CADMIUM}

both culture mediums exclusively coexisted with albumin fractions (This fractions contained mainly albumin.) as shown in Fig. 8-1, 2. While, when Cd dissolved in glycineTyrode's solution was added to the cultures, the $\mathrm{Cd}$ in this culture medium was not associated with any protein fractions as shown in Fig. 8-3. When the $\mathrm{CdCl}_{2}$ with a small dose $(3.88 \mu \mathrm{g})$ was added to the cultures, the $\mathrm{Cd}$ in the culture medium coexisted with albunin fractions exclusively (Fig. 8-4), but with a larger dose $(12.20 \mu \mathrm{g}$ ) the Cd was mainly associated with albumin fractions and partly with low molecular fractions. (Fig. 8-5)

5. The cell toxicity and chromatograph of culture medium containing metallothionein-Cd.

The cell toxicities of the cultures containing metallothionein-Cd were determined and the supernatants of these culture mediums were separated by gel filtration.

The metallothionein-Cd added to the cultures was less toxic than the equivalent

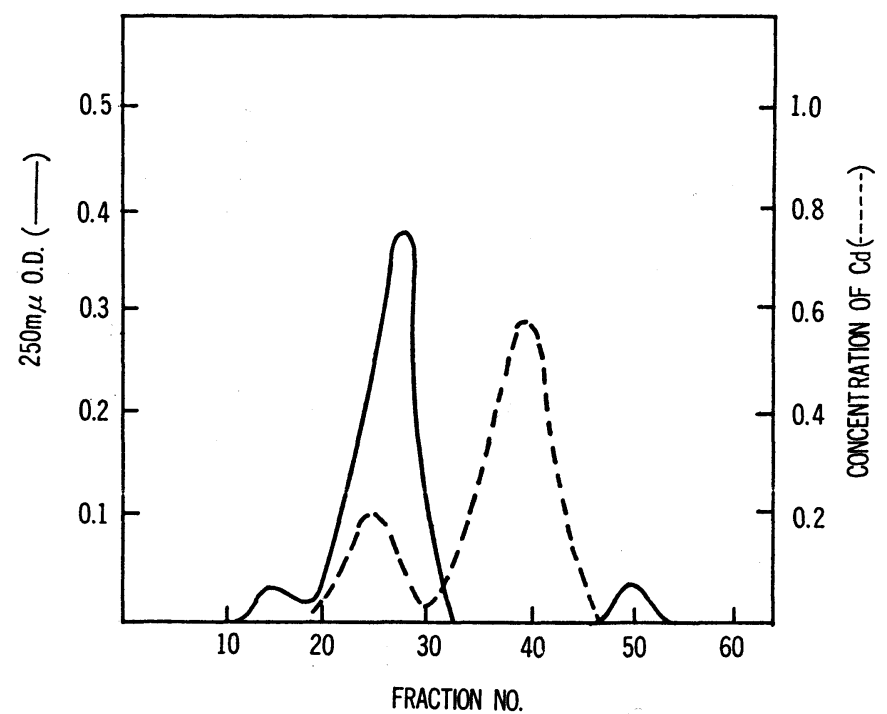

Fig. 9. Chromatograph of the culture medium of FM3A cells mixed with metallothionein-Cd.

(The sample apllied to the column contained $6.27 \mu \mathrm{g} \mathrm{Cd}$.)

Table 2. The amounts of $\mathrm{Cd}$ in albumin fractions and in metallothionein fractions and cell toxicity

\begin{tabular}{|c|c|c|c|}
\hline \multirow{2}{*}{$\begin{array}{l}\text { Amounts of metallothionein-Cd } \\
\text { added to the cultures } \\
\qquad(\mu \mathrm{g} / \mathrm{m} l)\end{array}$} & \multicolumn{2}{|c|}{ Cd recovered from culture medium } & Cell toxicity \\
\hline & $\begin{array}{c}\text { Cd-albumin } \\
(\mu \mathrm{g} / \mathrm{m} l)\end{array}$ & $\begin{array}{l}\text { Cd-metallothionein } \\
(\mu \mathrm{g} / \mathrm{m} l)\end{array}$ & $\%$ for control (Cell No.) \\
\hline 0.45 & 0.13 & 0.29 & 93.0 \\
\hline 1.10 & 0.26 & 0.78 & 77.5 \\
\hline 2.20 & 0.44 & 1.70 & 69.2 \\
\hline
\end{tabular}




\section{K. KOSHI}

amount of the other dissolved $\mathrm{Cd}$ as shown in Fig. 5.

One of the chromatographs of these culture mediums is shown in Fig. 9. As shown in the Figure, the $\mathrm{Cd}$ in the medium was partly associated with albumin fractions and mainly with the fractions which corresponded with metallothionein (M.W. about 10,000). The amounts of $\mathrm{Cd}$ in albumin fractions and metallothionein fractions were calculated separately from each chromatograph of the medium as shown in Table 2. As shown in the Table, it was found that the cell toxicity of metallothionein $\mathrm{Cd}$ was parallel to the amount of $\mathrm{Cd}$ which was combined with albumin fractions. Thus, it was considered that $\mathrm{Cd}$ bound with thionein in the culture medium did not exert toxic action on FM3A cells.

\section{Discussion}

The present series of experiments indicate the following results:

1). $\mathrm{Cd}, \mathrm{CdO}$ or $\mathrm{Cd}$ fume were more easily dissolved in protein or amino acid solution than in water or Tyrode's solution. But, there was no difference in the dissolution of $\mathrm{CdS}$ between in the former solutions and in the latter. The solubility of $\mathrm{Cd}, \mathrm{CdO}$ or Cd fume in albumin and glycine solution increased with increasing their concentration.

2). When the $\mathrm{Cd}$ dissolved in protein or amino acid solutions was added to the cultures, these dissolved $\mathrm{Cd}$ was found to be combined with protein or amino acid in the culture medium when observed after a $48 \mathrm{hr}$-incubation, as judged on the results of gel filtration of Sephadex G-200.

3). When $\mathrm{CdCl}_{2}$ dissolved in MEM supplemented with $10 \%$ fetal calf serum was added to the cultures, $\mathrm{Cd}$ was combined with albumin fractions in the case of adding a small dose of $\mathrm{CdCl}_{2}$, and in the case of a large dose, it was mainly combined with albumin fractions and partly remained in a free state.

4). The Cd dissolved in various solvents showed toxic action on the FM3A cells in proportion to the amount of $\mathrm{Cd}$ irrespective of the sort of the solvent.

5) Metallothionein-Cd was less toxic than the other dissolved form of $\mathrm{Cd}$ when compared at the equivalent amount of $\mathrm{Cd}$. In the culture medium metallothionein- $\mathrm{Cd}$ was partly combined with albumin fractions and mainly with metallothionein fractions and the toxic action of metallothionein-Cd was found in proportion to the amount of $\mathrm{Cd}$ combined with albumin fractions.

From the above results, it was assumed that the particulate $\mathrm{Cd}$ such as $\mathrm{Cd}$ powder, $\mathrm{Cd}$ fume or $\mathrm{CdO}$ was dissolved in culture medium containing many sorts of amino acid and further supplemented with serum. Thus, the dissolved $\mathrm{Cd}$ values depended on the amounts of amino acid and serum in culture medium. It was reported in the previous papers ${ }^{12) 6}$ that the dissolved $\mathrm{Cd}$ was more toxic than particulate $\mathrm{Cd}$ itself. Therefore, it was quite reasonable to assume that the cellular toxicity of particulate $\mathrm{Cd}$ in the cultures might be varied by the composition of the culture medium.

It was reported ${ }^{7)}$ that the toxic action of metal on the cells was reduced by the addi- 


\section{SOLUBILITY AND CELL TOXICITY OF CADMIUM}

tion of serum in culture medium. But, in the present study, the results of the cell toxicity of $\mathrm{Cd}$ dissolved in various solvents on FM3A cells depended on dissolved $\mathrm{Cd}$ values irrespective of the sort of the solvent. This fact seemed to be explained by the fact that $\mathrm{Cd}$ dissolved in protein or amino acid solution was being released in culture medium. The present results on column chromatographs, however, showed that in the case of the culture containing $\mathrm{Cd}$ dissolved in fetal calf serum or albumin solution, the $\mathrm{Cd}$ in the medium coexisted with albumin fractions when examined after the determination of cell toxicity. In the case of the culture containing $\mathrm{Cd}$ dissolved in glycine-Tyrode's solution, the $\mathrm{Cd}$ was not combined with any protein fractions. In this case it was considered that $\mathrm{Cd}$ may be combined with glycine because in the case of $\mathrm{CdCl}_{2}$, the $\mathrm{Cd}$ was mainly combined with the albumin fractions. Therefore, it was assumed that in the case of glycine, if $\mathrm{Cd}$ were free, perhaps the $\mathrm{Cd}$ should be associated with albumin fractions. In the column chromatographic procedure the $\mathrm{Cd}$ dissolved in the various solvents was exposed to $0.1 \mathrm{M}$ Tris $\mathrm{HCl}$ buffer on the column, it was, at present, obscure whether or not the $\mathrm{Cd}$ was combined with protein or amino acid on the column for above procedure. At least, if the results of column chromatograph were true, it was considered that the dissolved $\mathrm{Cd}$ combined with albumin fractions and dissolved $\mathrm{Cd}$ in free state had the same toxic action on the FM3A cells. These facts will be investigated for the other many metals.

As shown in the chromatograph of the culture medium containing metallothionein- $\mathrm{Cd}$, the $\mathrm{Cd}$ was mainly combined with metallothionein fractions and partly with albumin fractions, and the cell toxicity of these cultures depended on the amount of $\mathrm{Cd}$ combined with albumin fractions. It was considered that there were differences in the binding properties of $\mathrm{Cd}$ between with albumin fractions and with metallothionein fractions.

Just before publication, the author was aware of Weinzierl's report about dissolution of $\mathrm{Cd}$ in serum in 1972. This report showed about $80 \%$ of $\mathrm{Cd}$ in $\mathrm{Cd}$-serum was small diffusible molecules. That did not coincide with the present results.

\section{ACKNOWLEDGEMENT}

The author wishes to express sincere thanks to Dr. H. Sakabe of this institute for his invaluable advice. Futher, the author's cordial thanks are extended to other members of this institute; Dr. M. Kimura for presentation of metallothionein-Cd preparation, Mr. Y. Suzuki for his very useful advice on gel filtration method, Dr. K. Homma for preparation of Cd-fume sample and Mrs. K. Suzuki for her kind help. 


\section{K. KOSHI}

\section{REFERENCES}

1) Koshi, K., Homma, K., Kohyama, N. and Sakabe, H. (1975). Ind. Health, 13, 253.

2) Koshi, K., Homma, K. and Sakabe, H. (1978). Ind. Health, 16, 81.

3) Koshi, K., Homma, K. and Sakabe, H. (1975). Ind. Health, 13, 37.

4) Homma, K. (1966). Ind. Health, 4, 129.

5) Kimura, M., Otaki, N. and Imano, M. (1979). Methallothionein, Edited by Kagi, J.H.R. and Nordberg, M. Birkhauser Verlag, Basel, Boston, Stuttgart, in press.

6) Koshi, K. and Sakabe, H. Unpublished data.

7) Kano, E., Miyakoshi, J., Kajimoto, T., Matsumoto, J. and Konda, J. (1976). Jap. J. Ind. Health, 18, 502.

8) Weinzierl, S.M. and Webb, M. (1972). Brit. J. Cancer, 26, 279 